\title{
Article \\ Morphological and Phylogenetic Evidence for Recognition of Two New Species of Phanerochaete from East Asia
}

\author{
Dong-Qiong Wang ${ }^{1,2}(\mathbb{D})$ and Chang-Lin Zhao ${ }^{1,2,3,4, *(\mathbb{D})}$ \\ 1 Key Laboratory for Forest Resources Conservation and Utilization in the Southwest Mountains of China, \\ Ministry of Education, Southwest Forestry University, Kunming 650224, China; \\ fungiwangdongqiong@163.com \\ 2 College of Biodiversity Conservation, Southwest Forestry University, Kunming 650224, China \\ 3 Yunnan Key Laboratory for Fungal Diversity and Green Development, Kunming Institute of Botany, \\ Chinese Academy of Sciences, Kunming 650201, China \\ 4 School of Life Sciences, Tsinghua University, Beijing 100084, China \\ * Correspondence: fungi@swfu.edu.cn or fungichanglinz@163.com
}

Citation: Wang, D.-Q.; Zhao, C.-L. Morphological and Phylogenetic Evidence for Recognition of Two New Species of Phanerochaete from East Asia. J. Fungi 2021, 7, 1063. https:// doi.org/10.3390/jof7121063

Academic Editors: Vladimír Antonín and Hana Sevcikova

Received: 11 October 2021

Accepted: 9 December 2021

Published: 11 December 2021

Publisher's Note: MDPI stays neutral with regard to jurisdictional claims in published maps and institutional affiliations.

Copyright: (c) 2021 by the authors. Licensee MDPI, Basel, Switzerland. This article is an open access article distributed under the terms and conditions of the Creative Commons Attribution (CC BY) license (https:// creativecommons.org/licenses/by/ $4.0 /)$.

\begin{abstract}
Two new corticioid fungal species, Phanerochaete pruinosa and P. rhizomorpha spp. nov. are proposed based on a combination of morphological features and molecular evidence. Phanerochaete pruinosa is characterized by the resupinate basidiomata with the pruinose hymenial surface, a monomitic hyphal system with simple-septate generative hyphae and subcylindrical basidiospores measuring as 3.5-6.7 $\times 1.5-2.7 \mu \mathrm{m}$. Phanerochaete rhizomorpha is characterized by having a smooth hymenophore covered by orange hymenial surface, the presence of rhizomorphs, subulate cystidia, and narrower ellipsoid to ellipsoid basidiospores. Sequences of ITS + nLSU nrRNA gene regions of the studied specimens were generated and phylogenetic analyses were performed with maximum likelihood, maximum parsimony, and Bayesian inference methods. These phylogenetic analyses showed that two new species clustered into genus Phanerochaete, in which P. pruinosa was sister to P. yunnanensis with high supports (100\% BS, 100\% BT, $1.00 \mathrm{BPP})$; morphologically differing by a pale orange to greyish orange and densely cracked hymenial surface. Another species P. rhizomorpha was closely grouped with $P$. citrinosanguinea with lower supports; morphologically having yellow to reddish yellow hymenial surface, and smaller cystidia measuring as $31-48 \times 2.3-4.8 \mu \mathrm{m}$.
\end{abstract}

Keywords: corticioid fungi; Phanerochaetaceae; molecular systematics; taxonomy; Yunnan Province

\section{Introduction}

Corticioid fungi is a large group of Basidiomycota with simpler basidiomata with the diverse morphological features when compared with polypores, but the phylogenetic diversity of this group is less intensively studied [1,2]. In the subtropical-tropical areas, many corticioid taxa have not been discovered and described worldwide. The genus Phanerochaete P. Karst. is a member of the corticioid fungi, which is typified by P. alnea (Fr.) P. Karst. [3], and the genus is characterized by the resupinate, membranaceous basidiomata with or without rhizomorphs, a monomitic hyphal system with primarily simple-septate generative hyphae, clavate basidia with four sterigmata, and smooth, thin-walled, inamyloid basidiospores [1,4,5]. Index Fungorum (http:/ / www.indexfungorum.org; accessed on 9 December 2021) registers 187 specific and infraspecific names in Phanerochaete. The diversity and taxonomy of Phanerochaete s.l. in China have been studied for the last 30 years [6-19].

Molecular studies involving Phanerochaete based on the ribosomal DNA (rDNA) sequences, revealed the phylogenetic distribution of resupinate forms across the major clades of mushroom-forming fungi, in which P. chrysosporium Burds. nested into phlebioid clade in Polyporales [20]. Revisiting the taxonomy of Phanerochaete (Polyporales, Basidiomycota) using a four gene dataset and extensive ITS sampling indicated that Phanerochaete sensu lato was polyphyletic and distributed across nine lineages in the phlebioid clade, 
in which six lineages were associated to described genera [21]. Miettinen et al. [22]. explored the DNA-phylogeny-based and morphology-based to reconcile the polypores and genus concepts in the family Phanerochaetaceae, which the macromorphology of fruiting bodies and hymenophore construction did not reflect monophyletic groups, and Ceriporia inflata B.S. Jia and B.K. Cui was combined into Phanerochaete. Amplifying nrLSU, nrITS, and $\mathrm{rpb} 1$ genes across the Polyporales revealed that eleven genera clustered into family Phanerochaetaceae, and two families Hapalopilaceae and Bjerkanderaceae were placed as synonyms of Phanerochaetaceae [23]. Recently, the research supported by morphological studies and the phylogenetic analyses, showed that many new taxa of Phanerochaete s.s. were found and displayed the taxonomic status for the new taxa within genus Phanerochaete [14,19].

In 2018-2019, we collected the material supposedly belonging to the two undescribed species of corticioid fungi from Yunnan Province, China. We present the morphological and molecular phylogenetic evidence that support the recognition of two new species within the Phanerochaete s.s., based on the internal transcribed spacer (ITS) and regions nLSU sequences.

\section{Materials and Methods}

\subsection{Morphology}

The fruiting bodies were observed growing on the ground of broad-leaved treemixed forest. The fruiting bodies were dried in an electric food dehydrator at $40^{\circ} \mathrm{C}$, then sealed and stored in an envelope bag. They were then transported to Kunming where microscopic morphology and phylogeny to be studied at the mycology laboratory of Southwest Forestry University, Kunming, Yunnan Province, China. The for-study specimens were deposited at the herbarium of Southwest Forestry University (SWFC), Kunming, Yunnan Province, China. Macromorphological descriptions were based on field notes and photos captured in the field and lab. Color terminology follow Petersen [24]. Micromorphological data were obtained from the dried specimens, and observed under a light microscope following Dai [25]. The following abbreviations were used: $\mathrm{KOH}=5 \%$ potassium hydroxide water solution, $\mathrm{CB}=$ Cotton Blue, $\mathrm{CB}-=$ acyanophilous, IKI = Melzer's reagent, IKI $-=$ both inamyloid and indextrinoid, $\mathrm{L}=$ mean spore length (arithmetic average for all spores), $\mathrm{W}=$ mean spore width (arithmetic average for all spores), $\mathrm{Q}=$ variation in the $\mathrm{L} / \mathrm{W}$ ratios between the specimens studied, $n=\mathrm{a} / \mathrm{b}$ (number of spores (a) measured from given number of specimens (b)).

\subsection{Molecular Phylogeny}

CTAB rapid plant genome extraction kit-DN14 (Aidlab Biotechnologies Co., Ltd., Beijing, China) was used to obtain genomic DNA from dried specimens, according to the manufacturer's instructions followed previous study [26]. ITS region was amplified with primer pair ITS5 and ITS4 [27]. nLSU region was amplified with primer pair LR0R and LR7 (http:/ /lutzonilab.org/nuclear-ribosomal-dna/; accessed on 28 September 2021). The PCR procedure for ITS was as follows: initial denaturation at $95^{\circ} \mathrm{C}$ for $3 \mathrm{~min}$, followed by 35 cycles at $94{ }^{\circ} \mathrm{C}$ for $40 \mathrm{~s}, 58^{\circ} \mathrm{C}$ for $45 \mathrm{~s}$, and $72{ }^{\circ} \mathrm{C}$ for $1 \mathrm{~min}$, and a final extension of $72{ }^{\circ} \mathrm{C}$ for $10 \mathrm{~min}$. The PCR procedure for nLSU was as follows: initial denaturation at $94{ }^{\circ} \mathrm{C}$ for $1 \mathrm{~min}$, followed by 35 cycles at $94{ }^{\circ} \mathrm{C}$ for $30 \mathrm{~s}, 48^{\circ} \mathrm{C}$ for $1 \mathrm{~min}$ and $72{ }^{\circ} \mathrm{C}$ for $1.5 \mathrm{~min}$, and a final extension of $72^{\circ} \mathrm{C}$ for $10 \mathrm{~min}$. The PCR products were purified and directly sequenced at Kunming Tsingke Biological Technology Limited Company, Kunming, Yunnan Province, China. All newly generated sequences were deposited in NCBI GenBank (Table 1).

Table 1. List of species, specimens, and GenBank accession numbers of sequences used in this study.

\begin{tabular}{ccccc}
\hline \multirow{2}{*}{ Species Name } & Specimen No. & \multicolumn{2}{c}{ GenBank Accession No. } & References \\
\cline { 3 - 3 } & & ITS & nLSU & {$[21]$} \\
Bjerkandera adusta & FP-101236 & KP134982 & & \\
B. adusta & HHB-12826 & KP134983 & KP135198 & {$[21]$} \\
B. fumosa & Dai 12674B & MW507112 & MW520213 & {$[28]$} \\
\hline
\end{tabular}


Table 1. Cont.

\begin{tabular}{|c|c|c|c|c|}
\hline \multirow{2}{*}{ Species Name } & \multirow{2}{*}{ Specimen No. } & \multicolumn{2}{|c|}{ GenBank Accession No. } & \multirow{2}{*}{ References } \\
\hline & & ITS & nLSU & \\
\hline B. fumosa & Dai 21087 & MW507110 & & [28] \\
\hline Byssomerulius corium & FP-102382 & KP135007 & KP135230 & [21] \\
\hline B. corium & FP-107055 & KP135008 & & [21] \\
\hline Ceraceomyces serpens & HHB-15692-Sp & KP135031 & KP135200 & [21] \\
\hline C. serpens & L-11105 & KP135032 & & {$[21]$} \\
\hline Ceriporia purpurea & KKN-223-Sp & KP135044 & KP135203 & {$[21]$} \\
\hline C. purpurea & HHB-3964 & KP135042 & & [21] \\
\hline C. reticulata & RLG-11354 & KP135041 & KP135204 & [21] \\
\hline C. reticulata & L-7837 & KP135040 & & [21] \\
\hline Efibula gracilis & FD-455 & KP135027 & MZ637116 & [21] \\
\hline E. gracilis & FP-102052 & KP135028 & & [21] \\
\hline E. tropica & Wu 0809-8 & MZ636968 & MZ637130 & unpublished \\
\hline E. tropica & WEI 18-149 & MZ636967 & MZ637129 & unpublished \\
\hline Gloeoporus dichrous & FP-151129 & KP135058 & KP135213 & [21] \\
\hline G. pannocinctus & L-15726-Sp & KP135060 & KP135214 & [21] \\
\hline Hyphodermella poroides & Dai 12045 & KX008367 & KX011852 & [29] \\
\hline H. poroides & Dai 10848 & KX008368 & KX011853 & [29] \\
\hline H. rosae & FP-150552 & KP134978 & KP135223 & [21] \\
\hline H. rosae & MA-Fungi & FN600389 & JN939588 & [30] \\
\hline Irpex lacteus & FD-9 & KP135026 & KP135224 & [21] \\
\hline I. lacteus & FD-93 & KP135025 & & [21] \\
\hline $\begin{array}{l}\text { Meruliopsis } \\
\text { albostramineus }\end{array}$ & HHB-10729 & KP135051 & KP135229 & {$[21]$} \\
\hline M. albostramineus & L-9778 & KP135052 & & [21] \\
\hline M. taxicola & CBS 45548 & MH856432 & MH867978 & [31] \\
\hline M. taxicola & Kuljok 00/75 (GB) & EU118648 & & [32] \\
\hline $\begin{array}{l}\text { Phaeophlebiopsis } \\
\text { caribbeana }\end{array}$ & HHB-6990 & KP135415 & KP135243 & [21] \\
\hline P. caribbeana & FD-442 (TYPE) & KP135416 & & [21] \\
\hline P. ignerii & FD-425 & KP135418 & & [21] \\
\hline P. peiophoroides & FP-150577 & KP135417 & KP135273 & [21] \\
\hline Phanerochaete. albida & FD-31 & KP135308 & KP135210 & [19] \\
\hline P. alnea & OM 8110 & KP135171 & & [21] \\
\hline P. alnea & KHL 12054 & EU118653 & EU118653 & {$[32]$} \\
\hline P. argillacea & Wu 9712-18 & & GQ470656 & [13] \\
\hline P. arizonica & RLG-10248-sp & KP135170 & KP135239 & [21] \\
\hline P. australis & He 6013 & MT235656 & MT248136 & [19] \\
\hline P. australis & HHB-7105-sp & KP135081 & KP135240 & [21] \\
\hline P. australosanguinea & 20098 Tell $^{1}$ & & MH233928 & [33] \\
\hline P. australosanguinea & 20102 Tell & & MH233929 & [33] \\
\hline P. bambucicola & He 3606 & MT235657 & MT248137 & [19] \\
\hline P. bambucicola & Wu 0707-2 & MF399404 & MF399395 & [15] \\
\hline P. brunnea & He 4192 & MT235658 & MT248138 & [19] \\
\hline P. brunnea & He 1873 & KX212220 & KX212224 & [17] \\
\hline P. burdsallii & He 2066 & MT235690 & MT248177 & [19] \\
\hline P. burdsallii & CFMR: RF9JR & KU668973 & & unpublished \\
\hline P. burtii & HHB-4618-sp & KP135117 & KP135241 & [21] \\
\hline P. burtii & FD-171 & KP135116 & & [21] \\
\hline P. calotricha & Vanhanen-382 & KP135107 & & [21] \\
\hline P. canobrunnea & He 5726 & MT235659 & MT248139 & [19] \\
\hline P. canobrunnea & CHWC 1506-66 & LC412095 & LC412104 & [14] \\
\hline P. canolutea & Wu 9211-105 & & GQ470641 & [13] \\
\hline P. carnosa & He 5172 & MT235660 & MT248140 & [19] \\
\hline P. carnosa & HHB-9195 & KP135129 & KP135242 & [21] \\
\hline P. chrysosporium & HHB-6251 & KP135094 & KP135246 & [21] \\
\hline P. chrysosporium & He 5778 & MT235661 & MT248141 & [19] \\
\hline
\end{tabular}


Table 1. Cont.

\begin{tabular}{|c|c|c|c|c|}
\hline \multirow{2}{*}{ Species Name } & \multirow{2}{*}{ Specimen No. } & \multicolumn{2}{|c|}{ GenBank Accession No. } & \multirow{2}{*}{ References } \\
\hline & & ITS & nLSU & \\
\hline P. cinerea & He 6003 & & MT248172 & [19] \\
\hline P. citrinosanguinea & He 4298 & MT235691 & MT248178 & [19] \\
\hline P. citrinosanguinea & FP-105385-sp & KP135100 & KP135234 & [21] \\
\hline P. concrescens & He 4657 & MT235662 & MT248142 & [19] \\
\hline P. concrescens & Spirin 7322 & KР994380 & KP994382 & [34] \\
\hline P. cumulodentata & He 2995 & MT235664 & MT248144 & [19] \\
\hline P. cumulodentata & LE 298935 & KР994359 & KP994386 & [34] \\
\hline P. cystidiata & He 4224 & MT235665 & MT248145 & [19] \\
\hline P. cystidiata & Wu 1708-326 & LC412097 & LC412100 & [14] \\
\hline P. deflectens & FCUG 2777 & & GQ470644 & [13] \\
\hline P. ericina & He 4285 & MT235666 & MT248146 & [19] \\
\hline P. ericina & HНB-2288 & KP135167 & KP135247 & [21] \\
\hline P. exilis & HНB-6988 & KP135001 & KP135236 & [21] \\
\hline P. fusca & Wu 1409-163 & LC412099 & LC412106 & [14] \\
\hline P. hymenochaetoides & He 5988 & & MT248173 & [19] \\
\hline P. incarnata & He 20120728-1 & MT235669 & MT248149 & [19] \\
\hline P. incarnata & WEI 16-075 & MF399406 & MF399397 & [15] \\
\hline P. inflata & Dai 10376 & JX623929 & JX644062 & [35] \\
\hline P. inflata & Cui 7712 & JX623930 & JX644063 & [35] \\
\hline P. krikophora & HHB-5796 & KP135164 & KP135268 & [21] \\
\hline P. laevis & He 20120917-8 & MT235670 & MT248150 & [19] \\
\hline P. laevis & НHB-15519 & KP135149 & KP135249 & [21] \\
\hline P. leptocystidiata & He 5853 & MT235685 & MT248168 & [19] \\
\hline P. leptocystidiata & Dai 10468 & MT235684 & MT248167 & [19] \\
\hline P. livescens & He 5010 & MT235671 & MT248151 & [19] \\
\hline P. livescens & FD-106 & KP135070 & KP135253 & [21] \\
\hline P. magnoliae & He 3321 & MT235672 & MT248152 & [19] \\
\hline P. magnoliae & HHB-9829-sp & KP135089 & KP135237 & [21] \\
\hline P. metuloidea & He 2565 & & MT248163 & [19] \\
\hline P. metuloidea & He 2766 & MT235682 & MT248164 & [19] \\
\hline P. minor & He 3988 & MT235686 & MT248170 & [19] \\
\hline P. minor & He 3977 & & MT248169 & [19] \\
\hline P. parmastoi & He 4570 & MT235673 & MT248153 & [19] \\
\hline P. parmastoi & Wu 880313-6 & & GQ470654 & [13] \\
\hline P. porostereoides & He 1902 & KX212217 & KX212221 & [17] \\
\hline P. pruinosa & CLZhao 7712 & MZ435346 & MZ435350 & Present study \\
\hline P. pruinosa & CLZhao 7713 & MZ435347 & MZ435351 & Present study \\
\hline P. pseudomagnoliae & PP-25 & KP135091 & KP135250 & [21] \\
\hline P. pseudosanguinea & FD-244 & KP135098 & KP135251 & [21] \\
\hline P. queletii & HНB-11463 & KP134994 & KP135235 & [21] \\
\hline P. queletii & FP-102166 & KP134995 & & [21] \\
\hline P. rhizomorpha & CLZhao 10470 & MZ435348 & MZ435352 & Present study \\
\hline P. rhizomorpha & CLZhao 10477 & MZ435349 & MZ435353 & Present study \\
\hline P. rhodella & FD-18 & KP135187 & KP135258 & [21] \\
\hline P. robusta & Wu 1109-69 & MF399409 & MF399400 & [15] \\
\hline P. robusta & Ghobad 2288 & KP127068 & KP127069 & [16] \\
\hline P. sanguinea & НHB-7524 & KP135101 & KP135244 & {$[21]$} \\
\hline P. sanguineocarnosa & FD-359 & KP135122 & KP135245 & [21] \\
\hline P. sinensis & He 4660 & MT235688 & MT248175 & [19] \\
\hline P. sinensis & GC 1809-56 & MT235689 & MT248176 & [19] \\
\hline P. sordida & He 5400 & MT235676 & MT248157 & [19] \\
\hline P. sordida & FD-241 & KP135136 & KP135252 & [21] \\
\hline P. stereoides & He 5824 & MT235677 & MT248158 & [19] \\
\hline P. subceracea & FP-105974-R & KP135162 & KP135255 & [21] \\
\hline P. subrosea & He 2421 & MT235687 & MT248174 & [19] \\
\hline P. taiwaniana & He 5269 & MT235680 & MT248161 & [19] \\
\hline
\end{tabular}


Table 1. Cont.

\begin{tabular}{|c|c|c|c|c|}
\hline \multirow{2}{*}{ Species Name } & \multirow{2}{*}{ Specimen No. } & \multicolumn{2}{|c|}{ GenBank Accession No. } & \multirow{2}{*}{ References } \\
\hline & & ITS & nLSU & \\
\hline P. taiwaniana & Wu 0112-13 & MF399412 & MF399403 & [15] \\
\hline P. thailandica & 2015_07 & MF467737 & & [36] \\
\hline P. velutina & He 3079 & MT235681 & MT248162 & [19] \\
\hline P. velutina & Kotiranta 25567 & KP994354 & KP994387 & [34] \\
\hline P. xerophila & HHB-8509-Sp & KP134996 & KP135259 & [21] \\
\hline P. xerophila & KKN-172 & KP134997 & & [21] \\
\hline P. yunnanensis & He 2719 & MT235683 & MT248166 & [19] \\
\hline P. yunnanensis & He 2697 & & MT248165 & [19] \\
\hline Phlebiopsis flavidoalba & FD-263 & KP135402 & KP135271 & [21] \\
\hline P. flavidoalba & FD-374 & KP135403 & & [21] \\
\hline P. gigantea & FP-70857-sp & KP135390 & KP135272 & [21] \\
\hline P. gigantea & FP-101815 & KP135389 & & [21] \\
\hline Pirex concentricus & OSC-41587 & KP134984 & KP135275 & [21] \\
\hline P. concentricus & Kropp160Bup6-R & KP134985 & & [21] \\
\hline Rhizochaete filamentosa & HHB-3169 & KP135410 & KP135278 & [21] \\
\hline R. filamentosa & FP-105240 & KP135411 & & [21] \\
\hline R.radicata & FD-123 & KP135407 & KP135279 & [21] \\
\hline Terana caerulea & FP-104073 & KP134980 & KР135276 & [21] \\
\hline T. caerulea & T-616 & KP134981 & & [21] \\
\hline Trametopsis aborigena & Robledo 1238 & KY655337 & & [37] \\
\hline T. aborigena & Robledo 1236 & KY655336 & & [37] \\
\hline T. cervina & AJ-185 & JN165020 & JN164839 & [21] \\
\hline T. cervina & AJ-189 & JN165021 & & [21] \\
\hline
\end{tabular}

New sequences are shown in bold.

Sequences were aligned in MAFFT 7 (https:/ / mafft.cbrc.jp/alignment/server/; accessed on 28 September 2021) using G-INS-i strategy for ITS+nLSU combined dataset, and manually adjusted in BioEdit [38]. Aligned dataset was deposited in TreeBase (submission ID 28442). Phlebiopsis gigantea Fr. and Rhizochaete radicata (Henn.) Gresl., Nakasone and Rajchenb were selected as an outgroup for phylogenetic analyses of combined dataset following a previous study [19]. The taxon sampling strategy for the selection of sequences for phylogenetic trees was to choose (1) in a larger scale, focusing on the related genera in the families Phanerochaetaceae and Irpicaceae in Figure 1; (2) the related taxa based on BLAST search in GenBank within Phanerochaete s.l.; and (3) all species of Phanerochaete s.s.

Maximum parsimony analysis was applied to the combined (ITS+nLSU) dataset. Its approaches followed Zhao and $\mathrm{Wu}$ [26], and the tree construction procedure was performed in PAUP* version 4.0b10 [39]. All characters were equally weighted and gaps were treated as missing data. Trees were inferred using the heuristic search option with TBR branch swapping and 1000 random sequence additions. Max-trees were set to 5000, branches of zero length were collapsed and all parsimonious trees were saved. Clade robustness was assessed using bootstrap (BT) analysis with 1000 replicates [40]. Descriptive tree statistics: tree length (TL), consistency index $(\mathrm{CI})$, retention index (RI), rescaled consistency index $(\mathrm{RC})$, and homoplasy index (HI) were calculated for each Maximum Parsimonious Tree generated. Datamatrix was also analyzed using Maximum Likelihood (ML) approach with RAxML-HPC2 through the CIPRES Science Gateway (www.phylo.org; accessed on 28 September 2021) [41]. Branch support (BS) for ML analysis was determined by 1000 bootstrap replicates.

MrModeltest 2.3 [42] was used to determine the best-fit evolution model for the dataset for Bayesian inference (BI). BI was calculated with MrBayes 3.1.7a [43]. Four Markov chains were run for 2 runs from random starting trees for 10 million generations for ITS+nLSU (Figure 2). The first one-fourth of all generations was discarded as burn-in. The majority rule consensus tree of all remaining trees was calculated. Branches were considered as significantly supported if they received maximum likelihood bootstrap 
value (BS) $>70 \%$, maximum parsimony bootstrap value (BT) $>70 \%$, or Bayesian posterior probabilities $(\mathrm{BPP})>0.95$.

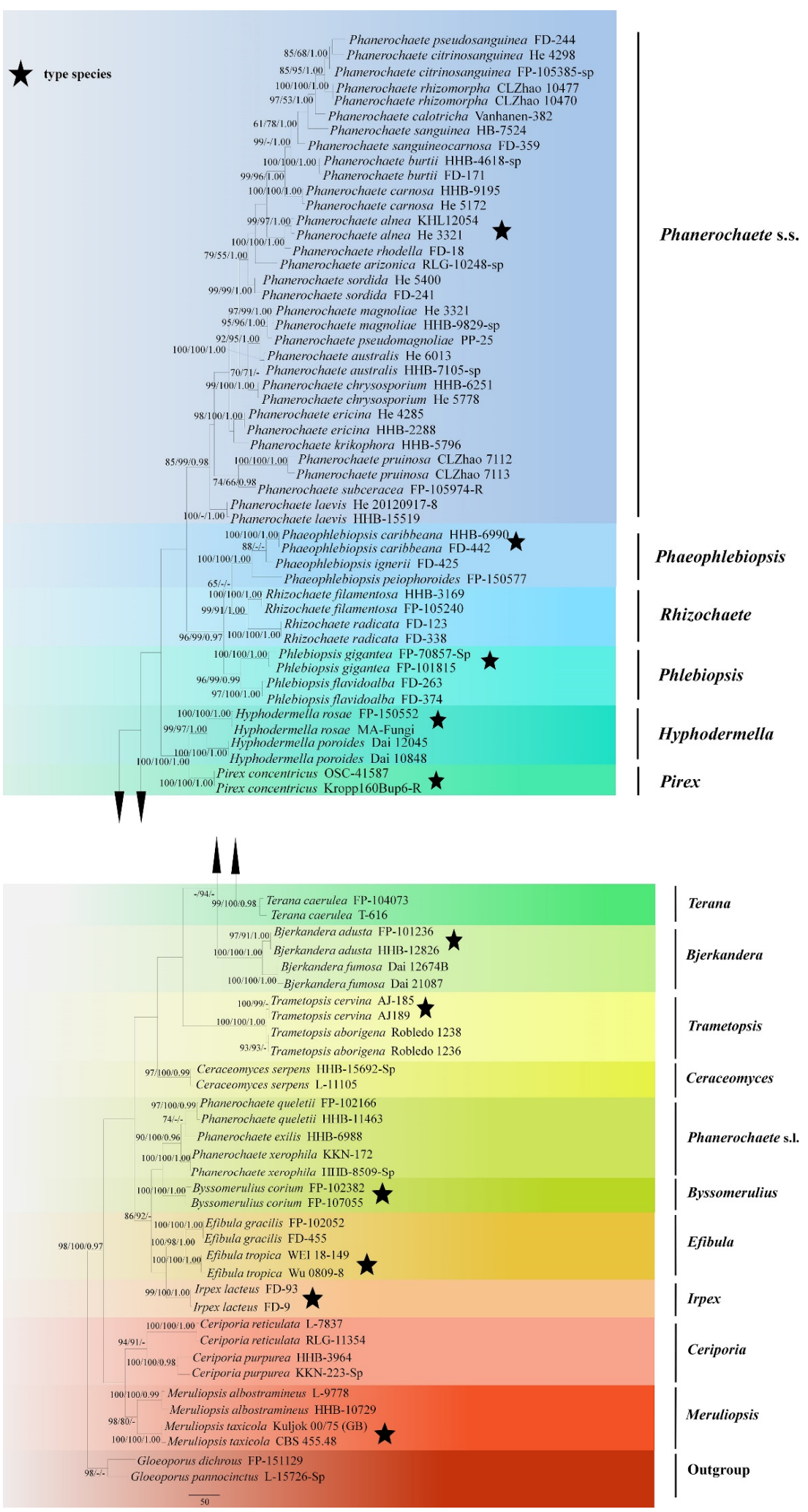

Figure 1. Maximum Parsimony strict consensus tree illustrating the phylogeny of two new species and related genera in Phanerochaetaceae and Irpicaceae based on ITS + nLSU sequences. Branches are labeled with maximum likelihood bootstrap values $>70 \%$, parsimony bootstrap values $>70 \%$ and Bayesian posterior probabilities $>0.95$, respectively. 


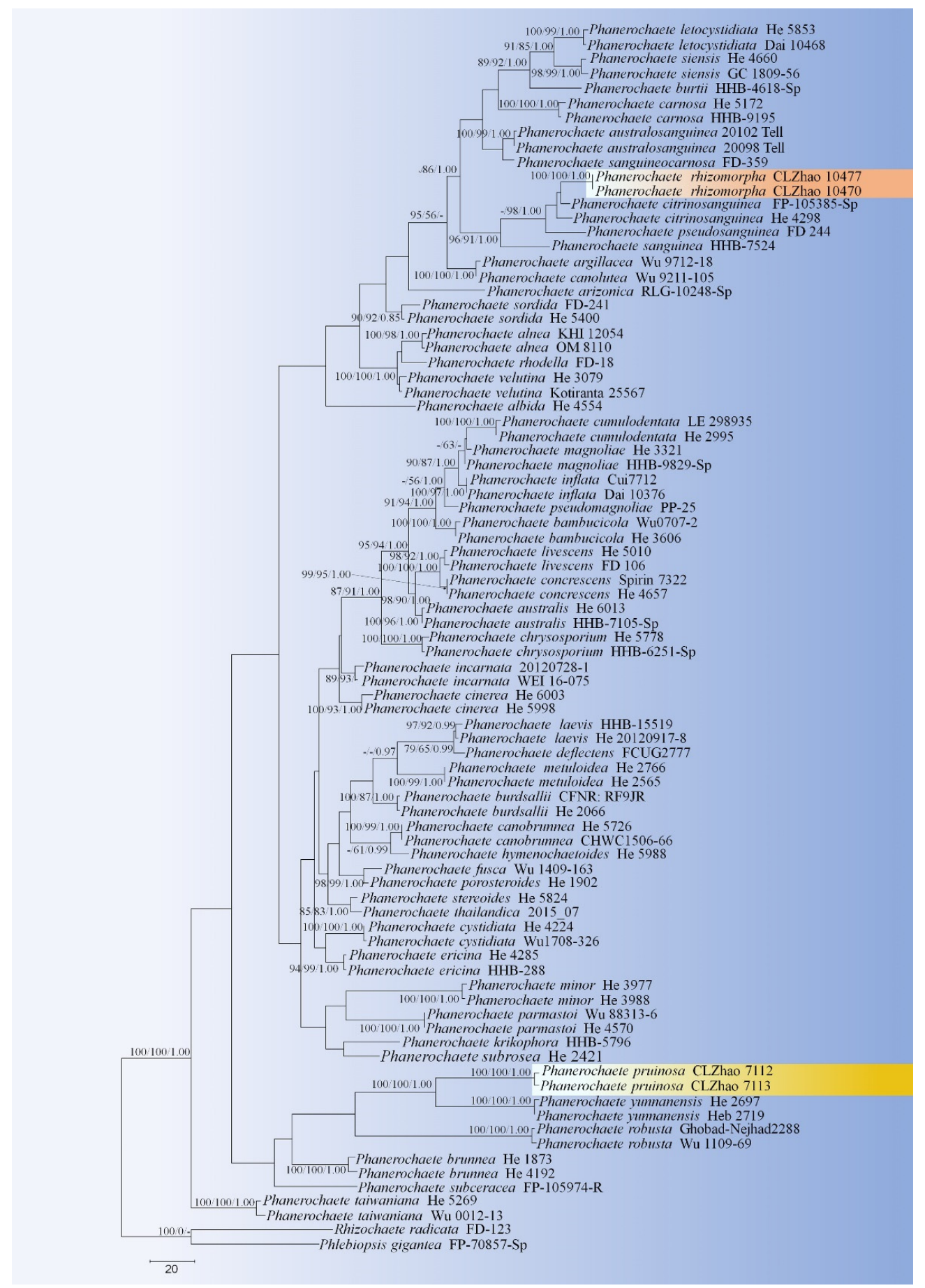

Figure 2. Maximum Parsimony strict consensus tree illustrating the phylogeny of two new species and related species in Phanerochaete based on ITS+nLSU sequences. Branches are labeled with maximum likelihood bootstrap values $>70 \%$, parsimony bootstrap values $>70 \%$ and Bayesian posterior probabilities $>0.95$, respectively. The yellow backgrounds indicate new species.

\section{Results}

\subsection{Molecular Phylogeny}

The ITS+nLSU dataset (Figure 1) included sequences from 86 fungal specimens representing 50 species. The dataset had an aligned length of 2368 characters, of which 1170 characters are constant, 598 are variable and parsimony-uninformative, and 600 are parsimony-informative. Maximum parsimony analysis yielded one equally parsimonious tree $(\mathrm{TL}=3476, \mathrm{CI}=0.3631, \mathrm{HI}=0.6369, \mathrm{RI}=0.7539, \mathrm{RC}=0.3512)$. Best model for the 
ITS + nLSU dataset estimated and applied in the Bayesian analysis was GTR+I+G (lset nst $=6$, rates $=$ invgamma; prset statefreqpr $=$ dirichlet $(1,1,1,1)$ ). Bayesian analysis and $\mathrm{ML}$ analysis resulted in a similar topology to MP analysis with an average standard deviation of split frequencies $=0.038487(\mathrm{BI})$, and the effective sample size (ESS) across the two runs is the double of the average ESS (avg ESS) $=303$.

The phylogeny (Figure 1) based on the combined ITS+nLSU sequences indicated that both species Phanerochaete pruinose and P. rhizomorpha clustered into Phanerochaete s.s and then P. pruinose grouped with P. subceracea (Burt) Burds.; P. rhizomorpha was sister to P. citrinosanguinea Floudas and Hibbett.

The ITS+nLSU dataset (Figure 2) included sequences from 83 fungal specimens representing 53 taxa. The dataset had an aligned length of 2017 characters, of which 1548 characters are constant, 164 are variable and parsimony-uninformative, and 395 are parsimony-informative. Maximum parsimony analysis yielded 35 equally parsimonious trees $(\mathrm{TL}=1900, \mathrm{CI}=0.4095, \mathrm{HI}=0.5905, \mathrm{RI}=0.6456, \mathrm{RC}=0.2644)$. Best model for the ITS+nLSU dataset estimated and applied in the Bayesian analysis was GTR+I+G (lset nst $=6$, rates $=$ invgamma; prset statefreqpr $=$ dirichlet $(1,1,1,1))$. Bayesian analysis and $\mathrm{ML}$ analysis resulted in a similar topology to MP analysis with an average standard deviation of split frequencies $=0.004260(\mathrm{BI})$, and the effective sample size (ESS) across the two runs is the double of the average ESS (avg ESS) $=309$.

The phylogram inferred from ITS+nLSU sequences (Figure 2) revealed that two new species were clustered into genus Phanerochaete s.s.; P. pruinosa sp. nova. was sister to P. yunnanensis Y.L. Xu and S.H. He with high supports (100\% BS, 100\% BT, 1.00 BPP), and then grouped with P. robusta Parmasto without supported data. Another species P. rhizomorpha sp. nova. was closely grouped with $P$. citrinosanguinea with lower supports, and then grouped with P. pseudosanguinea Floudas and Hibbett (-BS, 98\% BP and 1.00 BPP) and P. sanguinea (Fr.) Pouzar (96\% BS, 91\% BP and 1.00 BPP).

\subsection{Taxonomy}

Phanerochaete pruinosa C.L. Zhao and D.Q. Wang, sp. nov. Figures 3 and 4.

MycoBank no.: MB 841271.

Diagnosis: It differs from $P$. yunnanensis by its pruinose hymenophore with the white to slightly cream hymenial surface and lightly darkening in $\mathrm{KOH}$.

Holotype-China, Yunnan Province, Chuxiong, Zixishan National Forestry Park, on the bark of fallen angiosperms, $101.4^{\circ} \mathrm{E}, 25.1^{\circ} \mathrm{N}, 1$ July 2018, CLZhao 7113 (SWFC).

Etymology_pruinosa (Lat.): from Latin, referring to the white powder on hymenial surface of basidiomata.

Fruiting body-Basidiomata annual, resupinate, adnate, undetachable from substrate, membranaceous to coriaceous, without odor and taste when fresh, up to $15 \mathrm{~cm}$ long, $3 \mathrm{~cm}$ wide, 50-100 $\mu \mathrm{m}$ thick. Hymenial surface smooth to have small verrucous process, pruinose, white when fresh, white to slightly cream on drying; lightly darkening in $\mathrm{KOH}$. Margin sterile, narrow, white, attached.

Hyphal system-Hyphal system monomitic, generative hyphae simple-septa, colorless, thick-walled, unbranched, interwoven, 3-4.5 $\mu \mathrm{m}$ in diameter, subhymenial hyphae densely covered by larger crystals, basal hyphae regular; IKI-, CB-; tissues unchanged in $\mathrm{KOH}$.

Hymenium - Hymenial cystidia and cystidoles absent; basidia clavate to subcylindrical, with four sterigmata and a simple-septum, 13-24 $\mu \mathrm{m} \times 3.5-4.5 \mu \mathrm{m}$.

Spores-Basidiospores cylindrical, colorless, thin-walled, smooth, IKI-, CB-, (3.3-) 3.5-6.7(-7) $\mu \mathrm{m} \times 1.5-2.7(-2.9) \mu \mathrm{m}, \mathrm{L}=4.42 \mu \mathrm{m}, \mathrm{W}=1.94 \mu \mathrm{m}, \mathrm{Q}=2.21-2.35(\mathrm{n}=60 / 2)$.

Additional specimen examined-China, Yunnan Province, Zixishan National Forestry Park, on fallen branch of angiosperm, $101.4^{\circ} \mathrm{E}, 25.1^{\circ} \mathrm{N}, 1$ July 2018, C.L. Zhao 7112 (SWFC).

Habitat and ecology-Climate of the sample collection site is monsoon humid, and the forest type is evergreen broad-leaved forest, and the samples were collected on an angiosperm branch. 

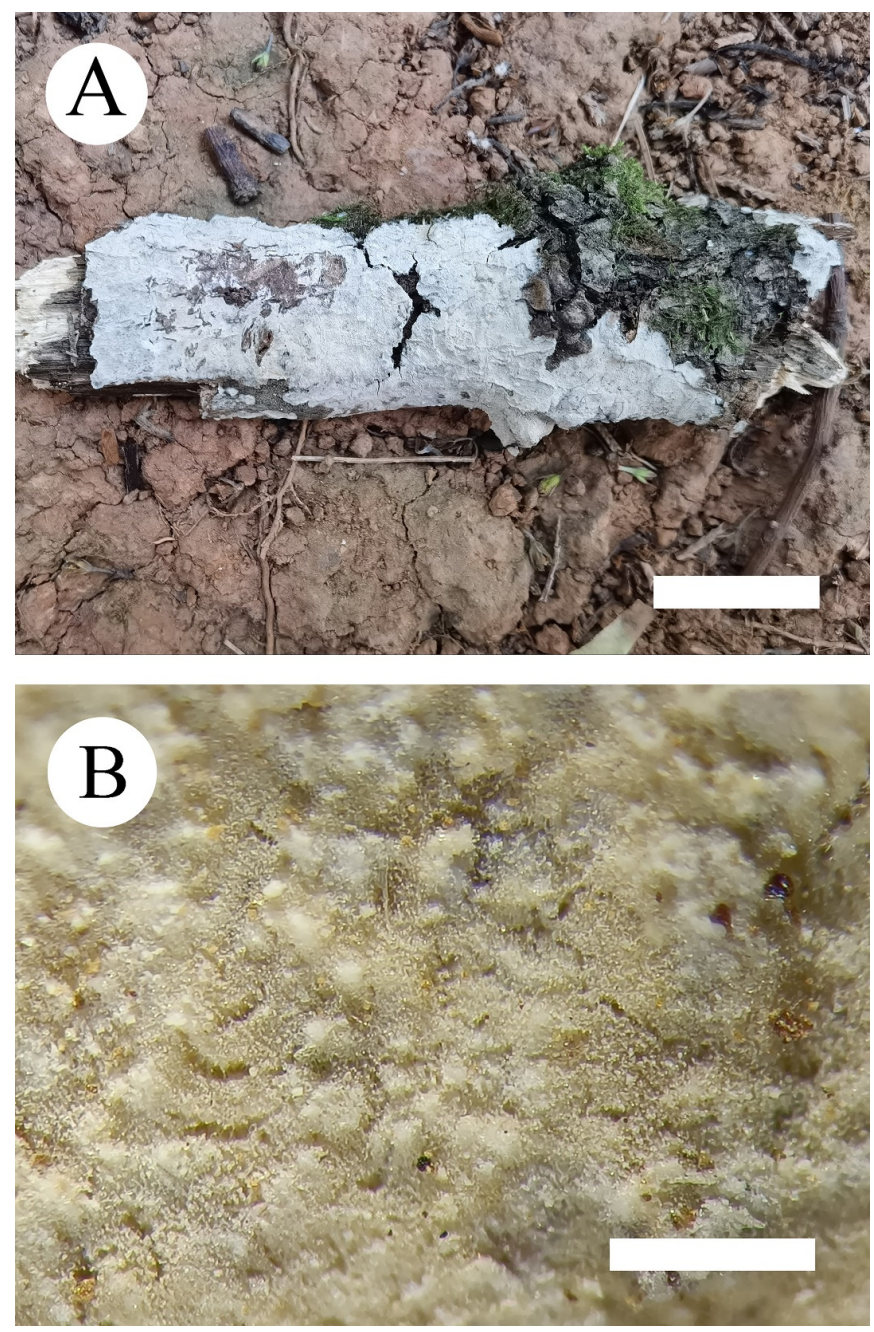

Figure 3. Basidiomata of Phanerochaete pruinosa (holotype) Bars: $(\mathbf{A})=2 \mathrm{~cm}$ and $(\mathbf{B})=1 \mathrm{~mm}$.
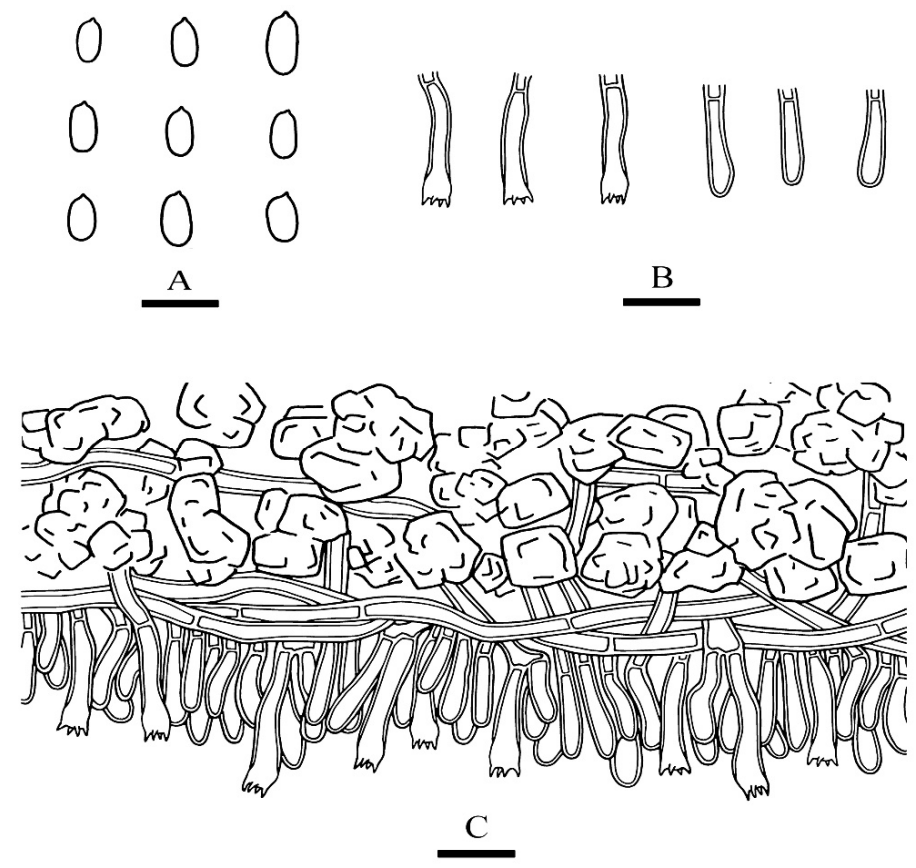

Figure 4. Microscopic structures of Phanerochaete pruinosa (holotype): basidiospores (A), basidia and basidioles (B), A section of hymenium (C). Bars: $(\mathbf{A})=5 \mu \mathrm{m},(\mathbf{B}, \mathbf{C})=10 \mu \mathrm{m}$. 
Phanerochaete rhizomorpha C.L. Zhao and D.Q. Wang sp. nov. Figures 5 and 6.
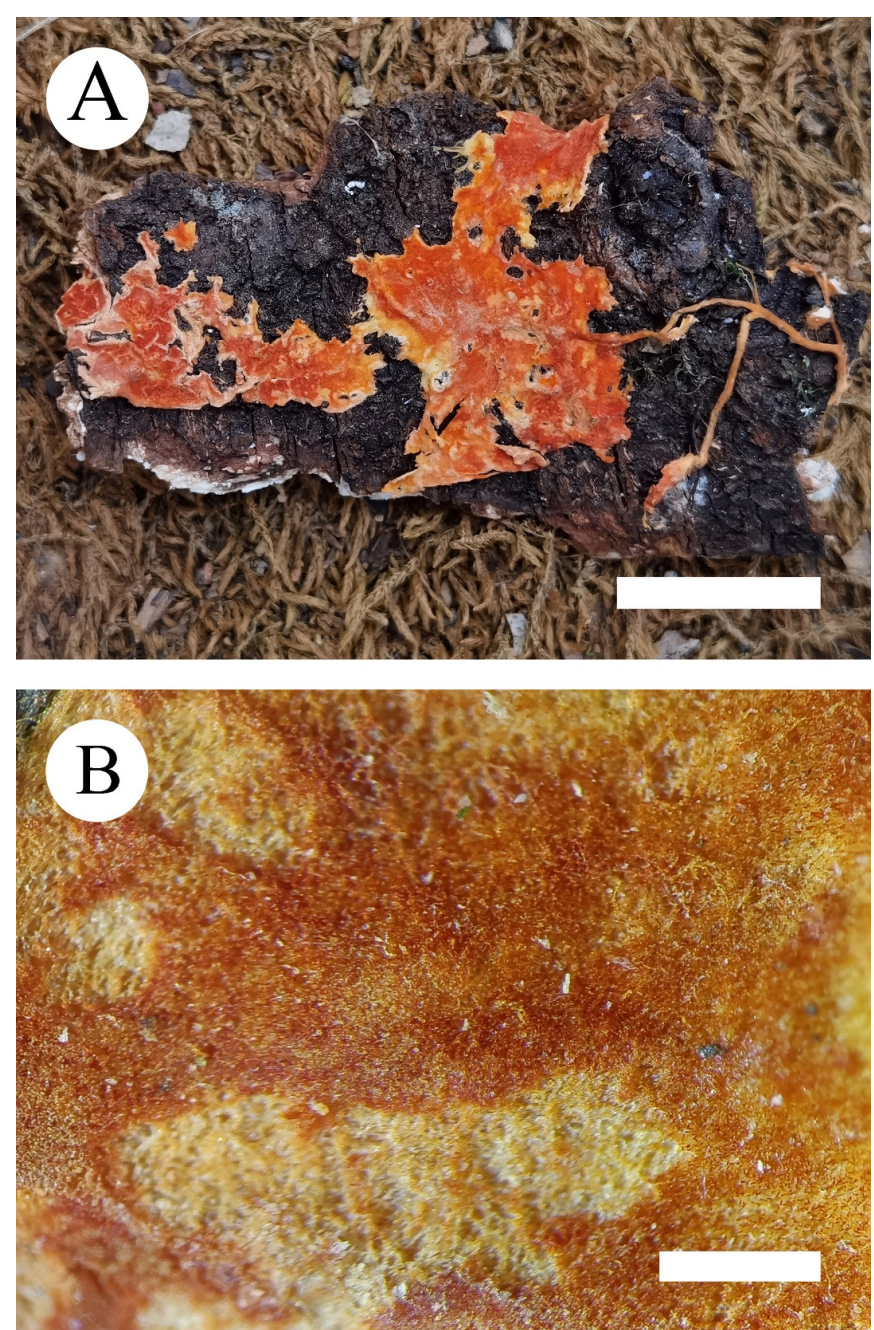

Figure 5. Basidiomata of Phanerochaete rhizomorpha (holotype) Bars: $(\mathbf{A})=2 \mathrm{~cm}$ and $(\mathbf{B})=1 \mathrm{~mm}$.

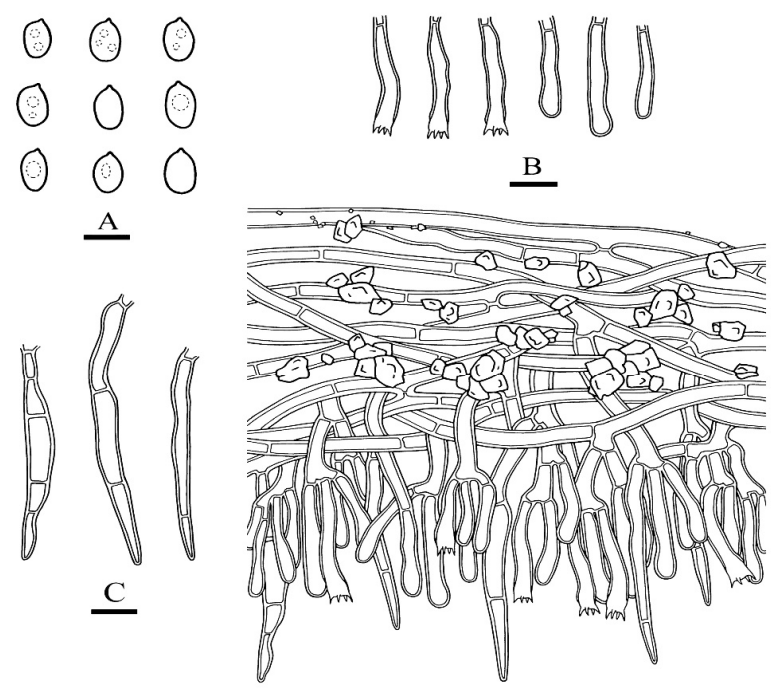

$\underline{\mathrm{D}}$

Figure 6. Microscopic structures of Phanerochaete rhizomorpha (holotype): basidiospores (A), basidia and basidioles (B), cystidia (C). A section of hymenium (D). Bars: $(\mathbf{A})=5 \mu \mathrm{m},(\mathbf{B}-\mathbf{D})=10 \mu \mathrm{m}$. 
MycoBank no.: MB 841272.

Diagnosis: It differs from $P$. citrinosanguinea by its orange hymenial surface and larger cystidia 48.5-71.5 $\mu \mathrm{m} \times 3-6.5 \mu \mathrm{m})$

Holotype-China, Yunnan Province, Dali, Nanjian Country, Lingbaoshan National Forestry Park, on the fallen branch of angiosperm, $24.7^{\circ} \mathrm{N}, 100.6^{\circ} \mathrm{E}, 10$ January 2019, C.L. Zhao 10,477 (SWFC).

Etymology-rhizomorpha (Lat.): from Latin, referring to the rhizomorphic basidiomata of the specimens.

Fruiting body-Basidiomata annual, resupinate, adnate, easily detachable from substrate, membranaceous, up to $5 \mathrm{~cm}$ long, $3 \mathrm{~cm}$ wide, 200-300 $\mu \mathrm{m}$ thick. Hymenial surface smooth, slightly orange when fresh, orange upon drying; lightly darkening in $\mathrm{KOH}$. Margin sterile, buff to slightly orange, up to $1 \mathrm{~mm}$ wide, rhizomorphic.

Hyphal system-Hyphal system monomitic, generative hyphae simple-septa, colorless, thick-walled, frequently branched, interwoven, 3-6.5 $\mu \mathrm{m}$ in diameter, basal hyphae regular, numerous crystals present among the abhymenium hyphae, IKI-, CB-; tissues unchanged in $\mathrm{KOH}$.

Hymenium-Hymenium cystidia subulate or tapering, colorless, thick-walled, with 2-4 septa, 48.5-71.5 $\mu \mathrm{m} \times 3-6.5 \mu \mathrm{m}$; basidia subcylindrical, with 4 sterigmata, $18.5-35.5 \mu \mathrm{m}$ $\times 3.5-5.5 \mu \mathrm{m}$.

Spores-Basidiospores narrower ellipsoid to ellipsoid, colorless, thin-walled, smooth, with oil 1-2 drops inside, IKI-, CB-, 4.5-5.8(-6) $\mu \mathrm{m} \times 2.7-3.6(-3.8) \mu \mathrm{m}, \mathrm{L}=5.07 \mu \mathrm{m}$, $\mathrm{W}=3.19 \mu \mathrm{m}, \mathrm{Q}=1.58-1.60(\mathrm{n}=62 / 2)$.

Additional specimen examined-China, Yunnan Province, Nanjian Country, Lingbaoshan National Forestry Park, on fallen branch of angiosperm, $24.7^{\circ} \mathrm{N}, 100.6^{\circ} \mathrm{E}, 10 \mathrm{Jan}-$ uary 2019, C.L. Zhao 10,470 (SWFC).

Habitat and ecology-Climate of the sample collection site is a transition between tropical and subtropical climate, and the forest type is the tropical monsoon evergreen broad-leaved forest, and the samples were collected on an angiosperm trunk.

\section{Discussion}

In the present study, two new species, Phanerochaete pruinosa C.L. Zhao and D.Q. Wang and P. rhizomorpha C.L. Zhao and D.Q. Wang spp. nov., are described based on phylogenetic analyses and morphological characters. The nucleotide differences of phylogenetically similar species to Phanerochaete pruinosa and P. rhizomorpha.

Phylogenetically, Xu et al. [19] revealed the taxonomy and phylogeny of Phanerochaete sensu stricto (Polyporales, Basidiomycota) with emphasis on Chinese collections, which showed that twenty-eight species of Phanerochaete s.s. from China are confirmed by morphology and DNA sequence data. In the present study (Figure 2), two new taxa clustered into Phanerochaete s.s., in which P. pruinosa was sister to P. yunnanensis, and then grouped with $P$. robusta. Another species $P$. rhizomorpha was closely grouped with $P$. citrinosanguinea with lower supports, and then grouped with P. pseudosanguinea and P. sanguinea. However, morphologically, P. yunnanensis is separated from $P$. pruinosa by having a pale orange to greyish orange and densely cracked hymenial surface [19]; P. robusta differs in its yellow basidiomata and two kinds of cystidia without encrustation, larger basidiospores $(5.5-7 \mu \mathrm{m}$ $\times 2.4-2.9 \mu \mathrm{m})$ and a boreal distribution [34]. Phanerochaete citrinosanguinea differs from P. rhizomorpha by having yellow to reddish yellow hymenial surface, and smaller cystidia (31-48 $\mu \mathrm{m} \times 2.3-4.8 \mu \mathrm{m})$ [21]; P. pseudosanguinea differs P. rhizomorpha in its light red or dark red hymenial surface, and narrower basidiospores (4-5.5 $\mu \mathrm{m} \times 2-2.5 \mu \mathrm{m})$ [21]; P. sanguinea is separated from $P$. rhizomorpha by having the thin-walled cystidia and the larger basidia (25-45 $\mu \mathrm{m} \times 4-6 \mu \mathrm{m})$ [1]; in addition, there is some coloration of wood as in P. sanguinea.

Morphologically, Phanerochaete pruinosa is similar to P. concrescens Spirin and Volobuev and P. sordida (P. Karst.) J. Erikss. and Ryvarden, based on presence of white or cream hymenial surface. However, P. concrescens differs from P. pruinosa by having the large 
basidia (27-39 $\mu \mathrm{m} \times 4-5 \mu \mathrm{m})$ [34]; P. sordida is separated from P. pruinosa by presence of cystidia and wider basidiospores $(5-7 \mu \mathrm{m} \times 2.5-3.5 \mu \mathrm{m})$ [1].

Phanerochaete rhizomorpha reminds four taxa of Phanerochaete based on the character by having the rhizomorph, P. burdsallii Y.L. Xu, Nakasone and S.H. He, P. leptocystidiata Y.L. Xu and S.H. He, P. sinensis Y.L. Xu, C.C. Chen and S.H. He and P. subrosea Y.L. Xu and S.H. He. However, P. burdsallii differs from P. rhizomorpha by having the cystidia encrusted with small crystals [19]; P. leptocystidiata differs in having a tuberculate hymenial surface and thin-walled cystidia encrusted at apex (24-30 $\mu \mathrm{m} \times 4-6 \mu \mathrm{m})$ [19]; P. sinensis differs in its thin-walled cystidia and the shorter basidia (17-22 $\mu \mathrm{m} \times 4-5 \mu \mathrm{m})$ [19]; P. subrosea is separated from P. rhizomorpha by having the thin-walled and smaller cystidia (33-55 $\mu \mathrm{m} \times$ 3-5 $\mu \mathrm{m})$ [19].

Phanerochaete rhizomorpha is similar to P. aurantiobadia Ghob.-Nejh., S.L. Liu, Langer and Y.C. Dai, P. cumulodentata (Nikol.) Parmasto and P. hymenochaetoides Y.L. Xu and S.H. He based on the character by the orange hymenial surface. However, P. aurantiobadia differs from P. rhizomorpha by having the larger basidiospores $(5-8.3 \mu \mathrm{m} \times 2-3 \mu \mathrm{m})$ [16]; $P$. cumulodentata differs from $P$. rhizomorpha by a tuberculate hymenophore and shorter basidia (16.7-28.3 $\mu \mathrm{m} \times 3.7-5.2 \mu \mathrm{m})$ [34]; P. hymenochaetoides differs from P. rhizomorpha by having both smaller cystidia $(30-45 \mu \mathrm{m} \times 3-4 \mu \mathrm{m})$ and basidiospores $(4-5.2 \mu \mathrm{m} \times$ $2-2.8 \mu \mathrm{m})$ [19].

In the ecology and biogeography, the taxa of Phanerochaete are a typical example of wood-rotting fungi, which are mainly distributed in Asia, Europe, and America, and the substrata are mostly hardwood [1,25], and this genus is an extensively studied group of Basidiomycota; nonetheless, the wood-rotting fungi diversity is still not well known in the subtropics and tropics [44-48]. The two new species, Phanerochaete pruinosa and P. rhizomorpha spp. nov., were found in subtropics, which enriches the diversity of woodrotting fungi.

Author Contributions: Conceptualization, C.-L.Z. and D.-Q.W.; methodology, C.-L.Z. and D.-Q.W.; software, D.-Q.W.; validation, C.-L.Z. and D.-Q.W.; formal analysis, D.-Q.W.; investigation, D.-Q.W.; resources, C.-L.Z.; data curation, D.-Q.W.; writing - original draft preparation, C.-L.Z. and D.-Q.W.; writing-review and editing, C.-L.Z. and D.-Q.W.; visualization, D.-Q.W.; supervision, C.-L.Z.; project administration, C.-L.Z.; funding acquisition, C.-L.Z. All authors have read and agreed to the published version of the manuscript.

Funding: The research was supported by the the National Natural Science Foundation of China (Project No. 32170004), Yunnan Fundamental Research Project (Grant No. 202001AS070043) and the High-level Talents Program of Yunnan Province (YNQR-QNRC-2018-111).

Institutional Review Board Statement: Not applicable for studies involving humans or animals.

Informed Consent Statement: Not applicable for studies involving humans.

Data Availability Statement: Publicly available datasets were analyzed in this study. This data can be found here: [https:/ /www.ncbi.nlm.nih.gov/, https:/ / www.mycobank.org/; https://www.treebase. org / treebase-web / home.html;jsessionid=6440D6056D96C04A8D29290992C18900, submission ID 28442; accessed on 16 November 2021].

Conflicts of Interest: The authors declare no conflict of interest.

\section{References}

1. Bernicchia, A.; Gorjón, S.P. Fungi Europaei 12: Corticiaceae s.l. Edizioni Candusso, Lomazzo; Candusso Edizioni: Origgio, Italy, 2010.

2. Larsson, K.-H.; Larsson, E.; Kõljalg, U. High phylogenetic diversity among corticioid homobasidiomycetes. Mycol. Res. 2004, 108, 983-1002. [CrossRef]

3. Karsten, P. Kritisk öfversigt af Finlan's Basidsvamper (Basidiomycetes, Gaster and Hymenomycetes). Bidr. Till Kännedom Av Finl. Nat. Och Folk. 1889, 48, 1-470.

4. Eriksson, J.; Hjortstam, K.; Ryvarden, L. The Corticiaceae of North Europe volume 5: Mycoaciella-Phanerochaete. Fungiflora Oslo 1978, 5, 987-1047.

5. Burdsall, H.H. A contribution to the taxonomy of the genus Phanerochaete. Mycol. Mem. 1985, 10, 1-165. 
6. Wu, S.H. The Corticiaceae (Basidiomycetes) subfamilies Phlebioideae, Phanerochaetoideae and Hyphodermoideae in Taiwan. Acta Bot. Fenn. 1990, 142, 1-123.

7. Wu, S.H. A study of the genus Phanerochaete (Aphyllophorales) with brown subicular hyphae. Mycotaxon 1995, 54, 163-172.

8. Wu, S.-H. Nine new species of Phanerochaete from Taiwan. Mycol. Res. 1998, 102, 1126-1132. [CrossRef]

9. $\mathrm{Wu}, \mathrm{S} . \mathrm{H}$. Six new species of Phanerochaete from Taiwan. Bot. Bull. Acad. Sin. 2000, 41, 165-174.

10. Wu, S.H. Two new species of Phanerochaete from Taiwan. Mycotaxon 2004, 90, 423-429.

11. Wu, S.H. Three new species of corticioid fungi from Taiwan. Bot. Stud. 2007, 48, 325-330.

12. Xiong, H.X.; Dai, Y.C. Notes on lignicolous corticioid fungi in China 3. Phanerochaete (Basidiomycota, Polyporales) in China. Mycosystema 2009, 28, 29-35.

13. Wu, S.-H.; Nilsson, H.R.; Chen, C.-T.; Yu, S.-Y.; Hallenberg, N. The white-rotting genus Phanerochaete is polyphyletic and distributed throughout the phleboid clade of the Polyporales (Basidiomycota). Fungal Divers. 2010, 42, 107-118. [CrossRef]

14. Wu, S.-H.; Chen, C.-C.; Wei, C.-L. Three new species of Phanerochaete (Polyporales, Basidiomycota). MycoKeys 2018, 41, 91-106. [CrossRef]

15. Wu, S.-H.; Chen, Y.-P.; Wei, C.-L.; Floudas, D.; Dai, Y.-C. Two new species of Phanerochaete (Basidiomycota) and redescription of $P$. robusta. Mycol. Prog. 2017, 17, 425-435. [CrossRef]

16. Ghobad-Nejhad, M.; Liu, S.-L.; Langer, E.; Dai, Y.-C. Molecular and morphological evidence reveal a new non-cystidiate species belonging to the core Phanerochaete (Polyporales). Mycol. Prog. 2015, 14, 68. [CrossRef]

17. Liu, S.L.; He, S.H. Phanerochaete porostereoides, a new species in the core clade with brown generative hyphae from China. Mycosphere 2016, 7, 648-655. [CrossRef]

18. Chen, C.-C.; Wu, S.-H.; Chen, C.-Y. Hydnophanerochaete and Odontoefibula, two new genera of phanerochaetoid fungi (Polyporales, Basidiomycota) from East Asia. MycoKeys 2018, 39, 75-96. [CrossRef] [PubMed]

19. Xu, Y.L.; Cao, Y.F.; Nakasone, K.K.; Chen, C.C.; He, S.H. Taxonomy and phylogeny of Phanerochaete sensu stricto (Polyporales, Basidiomycota) with emphasis on Chinese collections and descriptions of nine new species. Mycosphere 2020, 11, 1527-1552. [CrossRef]

20. Binder, M.; Hibbett, D.S.; Larsson, K.; Larsson, E.; Langer, E.; Langer, G. The phylogenetic distribution of resupinate forms across the major clades of mushroom-forming fungi. Syst. Biodivers. 2005, 3, 113-157. [CrossRef]

21. Floudas, D.; Hibbett, D.S. Revisiting the taxonomy of Phanerochaete (Polyporales, Basidiomycota) using a four gene dataset and extensive ITS sampling. Fungal Biol. 2015, 119, 679-719. [CrossRef]

22. Miettinen, O.; Spirin, V.; Vlasák, J.; Rivoire, B.; Stenroos, S.; Hibbett, D. Polypores and genus concepts in Phanerochaetaceae (Polyporales, Basidiomycota). MycoKeys 2016, 17, 1-46. [CrossRef]

23. Justo, A.; Miettinen, O.; Floudas, D.; Ortiz-Santana, B.; Sjökvist, E.; Lindner, D.; Nakasone, K.; Niemelä, T.; Larsson, K.-H.; Ryvarden, L.; et al. A revised family-level classification of the Polyporales (Basidiomycota). Fungal Biol. 2017, 121, 798-824. [CrossRef]

24. Petersen, J.H. The Danish Mycological Society's colour-chart. Foreningen til Svampekundskabens Fremme Greve 1996, 6, 1-6.

25. Dai, Y.C.; Xiong, H.X. Flora Fungorum Sinicorum Volume 42 Corticiaceae s.l. (1); Science Press: Beijing, China, 2012; 198 p.

26. Zhao, C.-L.; Wu, Z.-Q. Ceriporiopsis kunmingensis sp. nov. (Polyporales, Basidiomycota) evidenced by morphological characters and phylogenetic analysis. Mycol. Prog. 2016, 16, 93-100. [CrossRef]

27. White, T.J.; Bruns, T.; Lee, S.; Taylor, J.W. Amplification and direct sequencing of fungal ribosomal RNA genes for phylogenetics. PCR Protoc. A Guide Methods Appl. 1990, 18, 315-322.

28. Wang, C.-G.; Vlasák, J.; Dai, Y.-C. Phylogeny and diversity of Bjerkandera (Polyporales, Basidiomycota), including four new species from South America and Asia. MycoKeys 2021, 79, 149-172. [CrossRef] [PubMed]

29. Zhao, C.; Ren, G.-J.; Wu, F. A new species of Hyphodermella (Polyporales, Basidiomycota) with a poroid hymenophore. Mycoscience 2017, 58, 452-456. [CrossRef]

30. Telleria, M.T.; Dueñas, M.; Melo, I.; Martín, M.P. Morphological and molecular studies of Hyphodermella in the Western Mediterranean area. Mycol. Prog. 2010, 9, 585-596. [CrossRef]

31. Vu, D.; Groenewald, M.; De Vries, M.; Gehrmann, T.; Stielow, B.; Eberhardt, U.; Al-Hatmi, A.; Groenewald, J.Z.; Cardinali, G.; Houbraken, J.; et al. Large-scale generation and analysis of filamentous fungal DNA barcodes boosts coverage for kingdom fungi and reveals thresholds for fungal species and higher taxon delimitation. Stud. Mycol. 2019, 92, 135-154. [CrossRef]

32. Larsson, K.-H. Re-thinking the classification of corticioid fungi. Mycol. Res. 2007, 111, 1040-1063. [CrossRef]

33. Phookamsak, R.; Hyde, K.D.; Jeewon, R.; Bhat, D.J.; Jones, E.B.G.; Maharachchikumbura, S.; Raspé, O.; Karunarathna, S.C.; Wanasinghe, D.; Hongsanan, S.; et al. Fungal diversity notes 929-1035: Taxonomic and phylogenetic contributions on genera and species of fungi. Fungal Divers. 2019, 95, 1-273. [CrossRef]

34. Volobuev, S.; Okun, M.; Ordynets, A.; Spirin, V. The Phanerochaete sordida group (Polyporales, Basidiomycota) in temperate Eurasia, with a note on Phanerochaete pallida. Mycol. Prog. 2015, 14, 80. [CrossRef]

35. Jia, B.-S.; Zhou, L.-W.; Cui, B.-K.; Rivoire, B.; Dai, Y.-C. Taxonomy and phylogeny of Ceriporia (Polyporales, Basidiomycota) with an emphasis of Chinese collections. Mycol. Prog. 2013, 13, 81-93. [CrossRef]

36. Sádlíková, M. A new Phanerochaete (Polyporales, Basidiomycota) with brown subicular hyphae from Thailand. Mycosphere 2017, 8, 1024-1030. [CrossRef] 
37. Gómez-Montoya, N.; Drechsler-Santos, E.R.; Ferreira-Lopes, V.; Robledo, G.L.; Tomšovský, M.; Urcelay, C. New insights on Trametopsis Tomovsk (Polyporales Gum) based on phylogenetic evidences and morphological analyses of neotropical species. Phytotaxa 2017, 311, 155-167. [CrossRef]

38. Hall, T.A. Bioedit: A user-friendly biological sequence alignment editor and analysis program for Windows 95/98/NT. Nucleic Acids Symp. Ser. 1999, 41, 95-98.

39. Swofford, D.L. PAUP: Phylogenetic Analysis Using Parsimony (and Other Methods); Version 4.0b10; Sinauer Associates: Sunderland, MA, USA, 2002.

40. Felsenstein, J. Confidence limits on phylogenies: An approach using the bootstrap. Evolution 1985, 39, 783-791. [CrossRef] [PubMed]

41. Miller, M.A.; Holder, M.T.; Vos, R.; Midford, P.E.; Liebowitz, T.; Chan, L.; Hoover, P.; Warnow, T. The CIPRES Portals. CI-PRES. Available online: http://www.phylo.org/sub_sections / portal (accessed on 9 September 2020).

42. Nylander, J.A.A. MrModeltest v2. Program distributed by the author. Evolutionary Biology Centre, Uppsala University.ampignons de l'Équateur (Pugillus IV). Bull. L'Herb. Boissier 2004, 3, 53-74.

43. Ronquist, F.; Huelsenbeck, J.P. MrBayes 3: Bayesian phylogenetic inference under mixed models. Bioinformatics 2003, 19, 1572-1574. [CrossRef]

44. Alshammari, N.; Ameen, F.; AlKahtani, M.; Stephenson, S. Characterizing the assemblage of wood-decay fungi in the forests of northwest Arkansas. J. Fungi 2021, 7, 309. [CrossRef]

45. Blumenstein, K.; Bußkamp, J.; Langer, G.; Langer, E.; Terhonen, E. The diplodia tip blight pathogen Sphaeropsis sapinea is the most common fungus in Scots pines' mycobiome, irrespective of health status-A case study from Germany. J. Fungi 2021, 7, 607. [CrossRef] [PubMed]

46. Chen, P.Y.; Chuang, Y.C.; Wu, U.I.; Sun, H.Y.; Wang, J.T.; Sheng, W.H.; Chen, Y.C.; Chang, S.C. Mechanisms of azole resistance and trailing in Candida tropicalis bloodstream isolates. J. Fungi 2021, 7, 612. [CrossRef] [PubMed]

47. Guan, Q.-X.; Zhao, C.-L. Taxonomy and phylogeny of the wood-inhabiting fungal genus Hyphoderma with descriptions of three new species from East Asia. J. Fungi 2021, 7, 308. [CrossRef] [PubMed]

48. Štefániková, J.; Martišová, P.; Šnirc, M.; Kunca, V.; Árvay, J. The effect of Amanita rubescens Pers developmental stages on aroma profile. J. Fungi 2021, 7, 611. [CrossRef] 